\title{
Spatial characterization of Leptospira spp. infection in equids from the Brejo Paraibano micro-region in Brazil
}

Ruy Brayner Oliveira Filho ${ }^{1}$, Karla Campos Malta ${ }^{2}$, Vania Lucia Assis Santana ${ }^{3}$, Mabel Hanna Vance Harrop ${ }^{3}$, Danilo Tancler Stipp ${ }^{4}$, Daniel Friguglietti Brandespim ${ }^{5}$, Rinaldo Aparecido Mota ${ }^{6}$, José Wilton Pinheiro Júnior ${ }^{7}$

${ }^{1}$ Federal Rural University of Pernambuco (UFRPE), Dois Irmãos, Recife, Brazil; ${ }^{2}$ Center for Agricultural Sciences, Federal University of Paraiba (UFPB), Areia, Brazil; ${ }^{3}$ Division of Bacteriology, National Agricultural Laboratory in Pernambuco, Ministry of Agriculture, Livestock and Supply (MAPA/ Lanagro-PE), Recife, Brazil; ${ }^{4}$ Department of Veterinary Sciences, Center for Agricultural Sciences, Federal University of Paraiba (UFPB), Areia, Brazil; ${ }^{5}$ Academic Unity of Garanhuns, Federal Rural University of Pernambuco (UFRPE), Garanhuns, Brazil; ${ }^{6}$ Laboratory of Infectious and Contagious Diseases/DMV, Federal Rural University of Pernambuco, Recife, Brazil; ${ }^{7}$ Laboratory of Infectious and Contagious Diseases, Academic Unity of Garanhuns, Federal Rural University of Pernambuco, Garanhuns, Brazil

\begin{abstract}
The present study, the first to spatially characterize Leptospira spp. infection among equids in the Brejo Paraibano micro-region of the Paraiba state in the northeast of Brazil, investigated 257 animals in 26 farms properties. Serum samples from 204 horses, 46 mules and seven donkeys were serologically diagnosed using the microscopic agglutination test (MAT). The distribution of Leptospira spp. was studied by employing specific antigens from 24 different Leptospira serovars. All farms were georeferenced and their distribution visualised on a map of the Brejo Paraibano micro-region. In addition, rainfall data were obtained from the same year, in which the sampling was performed. Among the 20 farms found to harbour animals with leptospirosis, $14(70 \%)$ exhibited low prevalence, five $(25 \%)$ medium prevalence and one $(5 \%)$, high prevalence. Certain areas had a higher density of infected farms and required intervention to control the infection. Many serovars were widely distributed, while others were more common in particular areas. There was no significant association between the prevalence of Leptospira spp. infection and rainfall.
\end{abstract}

Keywords: horses, leptospirosis, serology, georeferencing, rainfall, Brazil.

\section{Introduction}

Leptospirosis is a zoonosis caused by different species of Leptospira spirochetes that are capable of infecting humans and several animal species, including cattle, pigs, horses, dogs and rodents. The disease has a worldwide distribution, but some serovars are found more frequently in certain geographical areas or in certain animal species (Oliveira and Pires Neto, 2004). The main clinical manifestations in livestock involve reproductive problems such as infertility, abortion in late pregnancy or birth of debilitated animals (Chiareli, 2007). In equids, leptospirosis manifests itself by recur-

\section{Corresponding author:}

José Wilton Pinheiro Júnior

Laboratory of Infectious and Contagious Diseases

Academic Unity of Garanhuns

Federal Rural University of Pernambuco

Av. Bom Pastor, Boa Vista, Garanhuns, PE 55296-901, Brazil

Tel. +55 873764 5518; Fax +558737645500

E-mail: jrwilton@uag.ufrpe.br rent uveitis as well as abortion and other reproductive disorders. It is an acute or chronic disease, affecting just one member of a herd or groups of animals. However, most infections are subclinical, and hence the true distribution is unknown (Jones et al., 2000).

Understanding the spatial dynamics of leptospirosis would aid the planning of control activities, resource allocation and preparation of a strategy in case of an outbreak as discussed by Barcellos and Bastos (1996). The application of spatial tools in studies of the epidemiology of leptospirosis can reveal patterns of infection, ways of transmission and the main risk factors. Geospatial techniques can also assist the implementation of plans of action and support measures taken against this disease (Bier, 2012). Geographical information systems (GIS) has been widely used to study leptospirosis in Brazil and in other countries where the disease is common (Ghneim et al., 2007; Magalhães et al., 2009; Soares et al., 2010; Melo et al., 2011; Belchior and Azevedo, 2012). Brazil has the largest herd of horses in Latin America and leptospirosis 


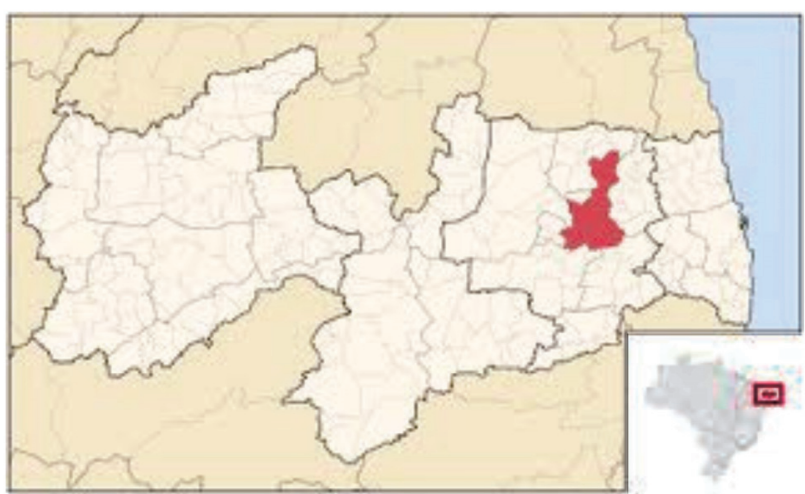

Fig. 1. The Brejo Paraibano micro-region (red) of the Paraiba state (white) in the northeast of Brazil.

plays a significant role for public health. The aim of the present study was to investigate the spatial characteristics of Leptospira spp. infection in equids from the Brejo Paraibano micro-region in the northeast of Brazil.

\section{Materials and methods}

The Brejo Paraibano micro-region is part of the Agreste meso-region in the Paraiba state, Brazil (Fig. 1). It consists of eight counties: Alagoa Grande, Alagoa Nova, Areia, Bananeiras, Borborema, Matinhas, Pilões and Serraria (IBGE, 2012).

A cross-sectional study was conducted to determine prevalence rates and the sampling plan was divided into two stages. In the first, all farm properties with 10 or more equids (the primary sampling unit) were selected. Twenty-six such properties were found, all of them part of the production chain of equid livestock in Brazil. In the second stage, a sample for each farm property was calculated using Win Episcope 2.0 software (University of Edinburgh, United Kingdom). Since no data were available for the occurrence of leptospirosis in this micro-region, an expected prevalence of $50 \%$ was arbitrarily assumed for calculating the

Table 1. Counties and equid species sampled.

\begin{tabular}{lrccc}
\hline \multirow{2}{*}{ County } & \multicolumn{4}{c}{ Number of animals } \\
\cline { 2 - 5 } & Horse & Mule & Donkey & Total \\
\hline Areia & 28 & 13 & 1 & 42 \\
Serraria & 9 & 4 & 0 & 13 \\
Alagoa Grande & 54 & 11 & 2 & 67 \\
Bananeiras & 93 & 12 & 3 & 108 \\
Pilões & 0 & 3 & 0 & 3 \\
Borborema & 4 & 2 & 1 & 7 \\
Alagoa Nova & 16 & 1 & 0 & 17 \\
Total & 204 & 46 & 7 & 257 \\
\hline
\end{tabular}

sample size. The confidence level was set at $95 \%$ and a statistical error of $10 \%$ was considered for each property. This predetermined number of equids (constituting the secondary sampling unit) was selected at random. In total, 257 blood samples from clinically healthy equids (horses, mules and donkeys) of different sexes were collected in the period between July and December 2011, corresponding to the seasons of winter and spring, respectively. Only one of the eight counties in the micro-region was not sampled, since there were no farm properties meeting the inclusion criteria (of 10 or more equids) in that area. Thus, only seven counties were surveyed (Table 1 ).

All serum samples were examined using the microscopic agglutination test (MAT) in accordance with the standards of the Ministry of Health (Brasil, 1995) and as recommended by the World Organization for Animal Health (OIE). The antigens used were recent live cultures of reference strains of 24 pathogenic Leptospira spp. serovars: Australis, Autumnalis, Batavie, Bratislava, Canicola, Castellonis, Celledoni, Copenhageni, Cynopteri, Djasiman, Grippotyphosa, Hardjo, Hebdomadis, Icterohaemorrhagiae, Javanica, Panama, Pomona, Pyrogenes, Saxkoebing, Sejroe, Sentot, Shermani, Tarassovi and Wolffi.

The equid serum samples were diluted 1/50 with phosphate buffered saline (PBS) and $0.1 \mathrm{ml}$ distributed into each of the 24 wells of a microplate, after which $0.1 \mathrm{ml}$ of each Leptospira serovar was added to the different wells, yielding a final volume of 0.2 $\mathrm{ml}$ at the dilution of 1:100. A negative control using PBS only and a positive control using a known serum from an infected animal were included in each run. The plates were read without cover slips using a microscope with dark-field condenser. Serum samples exhibiting a reduction of free leptospires in the range of $50 \%$ to $100 \%$ relative to the control were further tested through a series of two-fold dilutions. The highest serum dilution capable of agglutinating $50 \%$ or more of the Leptospira spirochetes, compared to the control, was considered to be the end point. A titre of $\geq 100$ considered to be positive (Lees and Gale, 1994; Baverud et al., 2009). None of the animals investigated had been vaccinated against leptospirosis. Prevalence was considered null when there were no positive animals, low when $<25 \%$ of the animals tested positive, medium when $25-50 \%$ of the animals tested positive and high if the positive number of animals exceeded $50 \%$. The likely infecting serovar on the farm was considered to be the one with the highest titre.

Each property was georeferenced to define and visu- 
alize their locations in physical space, i.e. identifying the farm properties on the map of the Brejo Paraibano micro-region. To that end, we used a global positioning system (GPS), configured to provide the positions in the coordinate latitude/longitude system of the Universal Transverse Mercator (UTM) projection and the SAD-69 System (South American Datum, 1969), which is the coordinate system of the cartographic base in the Brejo Paraibano micro-region.

The distribution of serovars by farm property was investigated as well as the relationship between rainfall and prevalence rates and density of the infection foci. The annual rainfall data were obtained from the Executive Agency for Water Management in the State of Paraiba (AESA, 2011). We also had access to precipitation measured at the farms during the period that sampling was performed. In order to map and identify spatial clusters, the georeferenced data were processed in TerraView 3.1.3 software (Brasil, 2006) using the kernel intensity estimator. This simulator involves a non-parametric technique that enables filtration of the variability of a data set, retaining the essential characteristics of local data (Bailey and Gatrell, 1995). The 26 sampled properties were part of the kernel shown.

\section{Results}

Animals testing serologically positive for Leptospira spp. infection were found in all of the seven counties sampled. With regard to the number of cases in each place, $76.9 \%(20 / 26)$ of the farms tested possessed at least one infected animal. Of these 20 farm properties, low prevalence dominated, i.e. $14(70.0 \%)$ displayed few infections, while five $(25.0 \%)$ had medium-level rates and high prevalence was only found in one $(5.0 \%)$ (Fig. 2). The lowest prevalence was found in the Alagoa Nova county.

Only a minority of animals were found to be infected and those which tested positive had generally low titres (Table 2). Many serovars were widely distributed in the study area, but some were more frequent in certain areas. Their distribution by farm property is shown in Fig. 3. This figure should be consulted together with Table 2, as it shows the spectrum of titres of the different serovars. The serovar Panama was widely distributed and it was detected in $71.4 \%$ of the counties surveyed in the micro-region. On the other hand, only one animal reacted serologically against the Australis antigen, and the serovar Hardjo was detected in only two contiguous counties. This former serovar, belonging to the same serogroup as



Fig. 2. Distribution and prevalence of positive serology for Leptospira spp. infection in the Brejo Paraibano micro-region, Paraiba state, Brazil.

Bratislava, was detected in the county of Bananeiras. Also the Icterohaemorrhagiae serovar was identified on a single farm property in the present study in the county of Areia. Among the nine animals positive for the serovar Grippotyphosa, eight were from the county of Bananeiras and one from the contiguous county of Borborema. These values corresponded to $50 \%$ of the total number of positive animals in each of these two counties. The serovar Pyrogenes was found on all of the positive farms properties in the county of Alagoa Grande. It was also considered to be the likely infecting serovar on two other properties located in the counties of Borborema and Serraria, which share a border.

Annual precipitation in the counties and the prevalence of positive serology for each property are shown in Fig. 4. The greatest rainfall in the year of sampling occurred between April and July (AESA, 2011). The amount of precipitation used was the highest figure found in the county. The middle counties of the study area had the highest annual rainfall, while Alagoa Nova in the south had the lowest. 


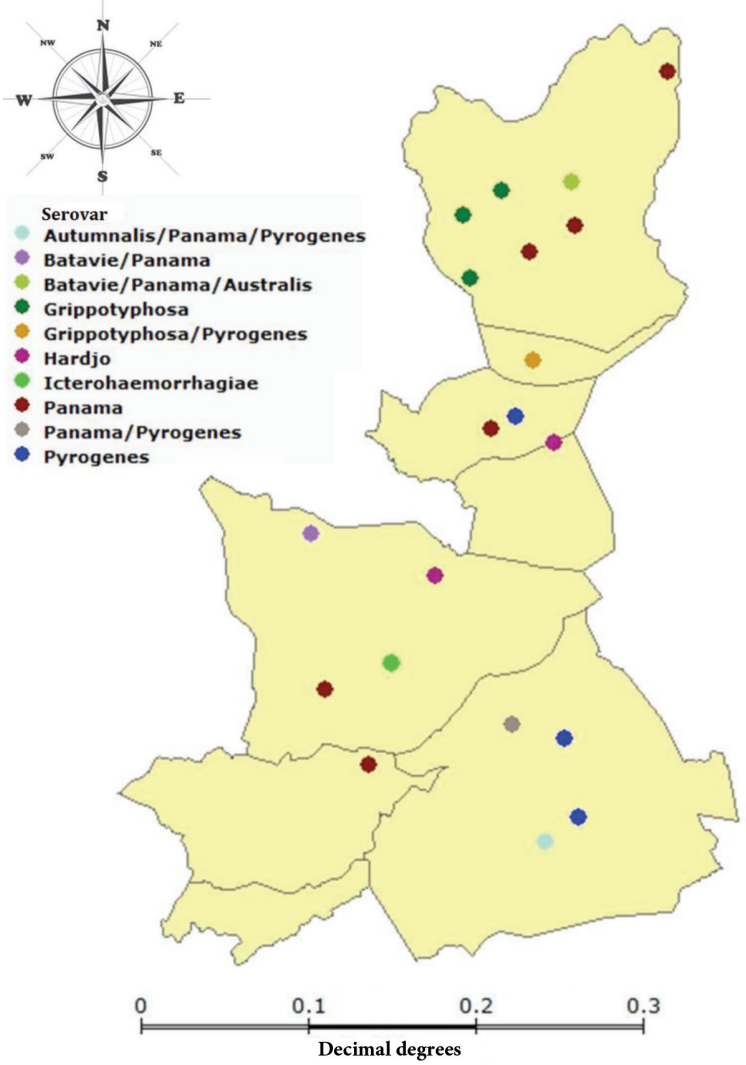

Fig. 3. Distribution of serovars of Leptospira spp. in properties with seropositive equids in the Brejo Paraibano micro-region, Paraiba state, Brazil.
Most farms exhibited low prevalence rates but, as can be seen from Fig. 2, there were also farms with higher prevalence, particularly in the north and the south. This can be seen more clearly in Fig. 5 that shows the results of the kernel intensity study. The Kernel intensity study revealed high, medium and low intensity of prevalence in the counties of Bananeiras, Alagoa Grande/Serraria and Areia, respectively. Because of this situation, these areas are priorities for a possible intervention for infection control.

\section{Discussion}

This is the first epidemiological study in the Brejo Paraibano micro-region aiming to spatially characterize Leptospira spp. infection in equids. Because of the zoonotic nature of Leptospira infection, the knowledge of distribution of serovars is important, and the differences between regions and species should be considered. The total sample had about four times more horses than mules and only very few donkeys, which makes comparisons between the three types of equid difficult. However, even when taking this into account, it is clear that horses were more commonly infected (Table 2). It is also clear that only a minority of the animals were found to be infected and that

Table 2. Distribution of the serovars of Leptospira spp. in equids of the Brejo Paraibano micro-region, Paraiba state, Brazil.

\begin{tabular}{|c|c|c|c|c|c|c|c|c|c|c|c|c|c|c|c|}
\hline \multirow{3}{*}{ Serovar } & \multicolumn{12}{|c|}{ Titre } & \multirow{2}{*}{\multicolumn{3}{|c|}{ Total }} \\
\hline & \multicolumn{3}{|c|}{100} & \multicolumn{3}{|c|}{200} & \multicolumn{3}{|c|}{400} & \multicolumn{3}{|c|}{800} & & & \\
\hline & $\mathrm{H}$ & $\mathrm{M}$ & $\mathrm{D}$ & $\mathrm{H}$ & $\mathrm{M}$ & $\mathrm{D}$ & $\mathrm{H}$ & $\mathrm{M}$ & $\mathrm{D}$ & $\mathrm{H}$ & $\mathrm{M}$ & $\mathrm{D}$ & $\mathrm{H}$ & $\mathrm{M}$ & $\mathrm{D}$ \\
\hline Australis & - & - & - & - & - & - & 1 & - & - & - & - & - & 1 & - & - \\
\hline Autumnalis & 2 & - & - & - & - & - & - & - & - & - & - & - & 2 & - & - \\
\hline Batavie & 1 & - & 1 & 1 & - & - & 1 & - & - & - & - & - & 3 & - & 1 \\
\hline Canicola & - & - & - & 1 & - & - & - & - & - & - & - & - & 1 & - & - \\
\hline Copenhageni & 1 & - & - & - & - & - & - & - & - & - & - & - & 1 & - & - \\
\hline Grippotyphosa & 5 & 1 & - & 1 & - & - & 1 & - & 1 & - & - & - & 7 & 1 & 1 \\
\hline Hardjo & 1 & - & - & - & - & - & - & - & - & - & 1 & - & 1 & 1 & - \\
\hline Icterohaemorrhagiae & - & - & - & - & - & - & 1 & - & - & - & - & - & 1 & - & - \\
\hline Panama & 11 & 2 & - & 1 & - & - & 2 & - & - & - & - & - & 14 & 2 & - \\
\hline Pyrogenes & 4 & 1 & - & - & 1 & - & 2 & - & - & 1 & - & - & 7 & 2 & - \\
\hline Shermani & 2 & - & - & - & - & - & - & - & - & - & - & - & 2 & - & - \\
\hline Tarassovi & 1 & - & - & - & - & - & - & - & - & - & - & - & 1 & - & - \\
\hline Total & 28 & 4 & 1 & 4 & 1 & - & 8 & - & 1 & 1 & 1 & - & 41 & 6 & 2 \\
\hline
\end{tabular}

Conventions: $\mathrm{H}=$ Horse; $\mathrm{M}=$ Mule; $\mathrm{D}=$ Donkey. 


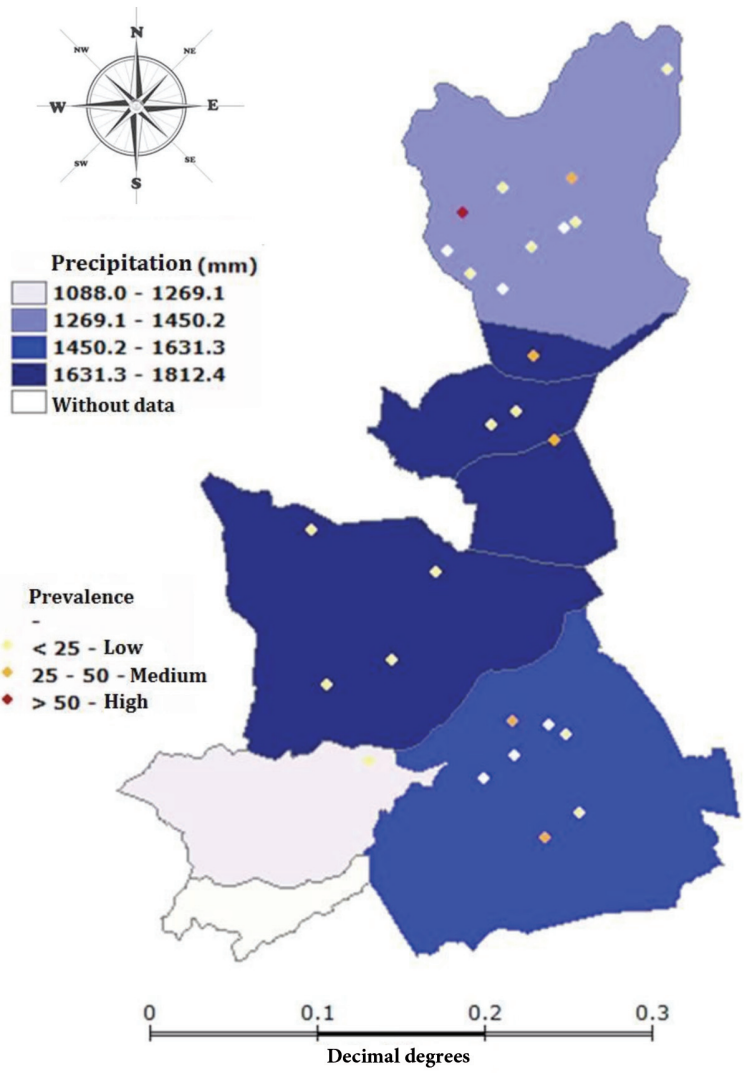

Fig. 4. Annual precipitation in the counties studied and the prevalence of Leptospira spp. infection.

those which tested positive had generally low titres.

The use of MAT to detect antibodies to Leptospira spp. permitted visualization of the distribution of animals that tested positive for Leptospira spp. in the Brejo Paraibano micro-region, as well as the predominant serovars. Cut-off at the titre level of 100 was decided to make sure that all titres reported indeed reflect a true infection by Leptospira spp. Higher titres, especially at the level of $\geq 400$, demonstrate recent contacts with leptospires, while lower ones, especially 100, suggest low-level, chronic or past infection. However, low titres can also indicate the early stage of an infection.

Animals testing positive were identified in all of the counties surveyed. The lowest prevalence was found in the county of Alagoa Nova, but the prevalence rates found were in general randomly spread over the study area. The high number of infection foci $(76.9 \%)$ suggests that Leptospira spp. infection is widely distributed in the Brejo Paraibano micro-region. All farms in the counties of Borborema, Serraria, Pilões, Areia and Alagoa Nova showed positive animals. In the counties of Bananeiras and Alagoa Grande, the percentage of positive farms was $70.0 \%$ and $57.1 \%$, respectively.

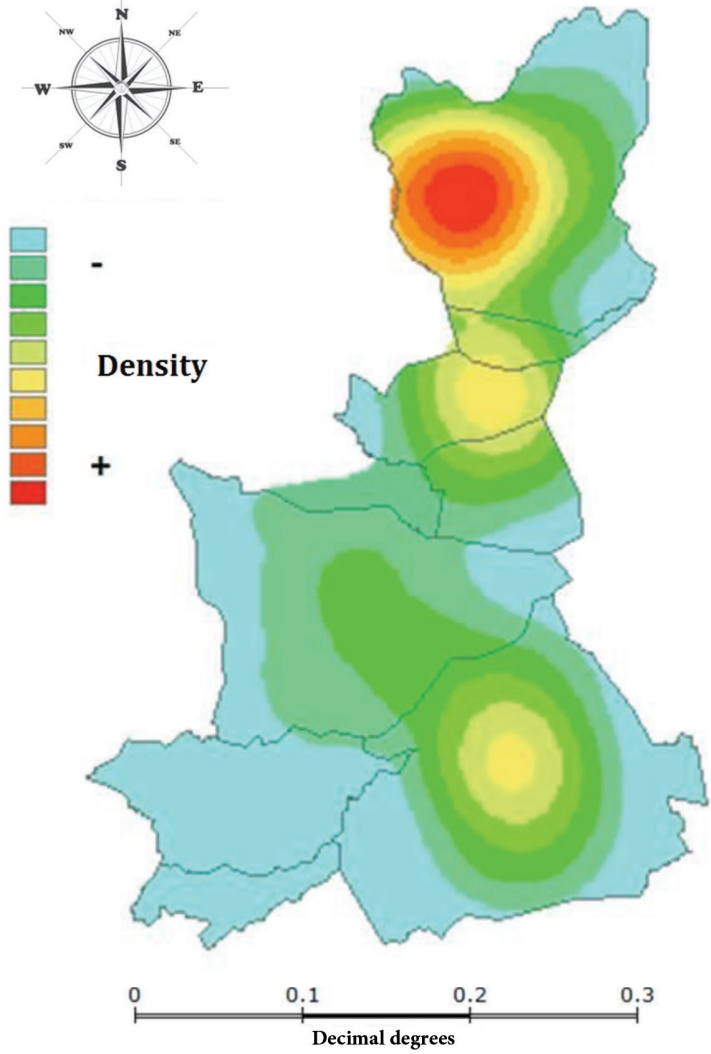

Fig. 5. Kernel density of the prevalence for positive serology for Leptospira spp. infection in the Brejo Paraibano micro-region, Paraiba state, Brazil.

However, further studies are needed to classify if it as an enzootic organism.

It was not totally unexpected to find the serovar Australis as it has been observed by Jardim et al. (1978) in Goiás and on the island of Algodoal/Pará by Moraes et al. (2010). Nevertheless, this serovar is uncommon and we only found one case, while Linhares et al. (2005), who studied the prevalence of serovars of Leptospira interrogans in 182 serum samples from horses of the Goiânia micro-region using the MAT method, did not find any positive results for this serovar. The fact that the Icterohaemorrhagiae serovar was also only identified on a single property in the present study is more controversial, as this serovar has been found in many studies and is regarded as one of the most prevalent ones in the country (Langoni et al., 2004; Gomes et al., 2007; Hashimoto et al., 2007; Jorge et al., 2011; Coiro et al., 2012). The findings with respect to Grippotyphosa may indicate a specific enzootic area for this serovar in the Bananeiras and Borborema counties. The observation of the serovar Pyrogenes on all positive properties in the county of Alagoa Grande may indicate a similar predilection for this area. 
The lowest level of prevalence of Leptospira spp. infection was found in the county of Alagoa Nova, which also had the lowest rainfall, is accordance with Odontsetseg et al. (2005) who observed a higher prevalence in humid environments than in dry areas and Finger (2012), who observed a positive correlation between rainfall and Leptospira serology. However, we found no clear association between the amount of precipitation and Leptospira infection, since the low-prevalence farms were spread randomly over the study area, while those with higher rates were absent from the middle region, and instead found in the north or south, which had less rain (Fig. 4). Neither did the kernel intensity results support for such an association (Fig. 5), indicating that other factors or indirect links must be involved. Still, regional differences in prevalence may be partly related to climatic conditions as leptospires excreted by infected animals can remain infectious for long periods of time in humid climates (Jung et al., 2010), whereas they have less chance of propagating the infection in drier areas.

The kernel results enabled the characterization of patterns of Leptospira spp. infection with some areas having a higher density of infection foci than others, e.g. the counties of Bananeiras, Alagoa Grande, Serraria and Areia, an indication that should lead to the implementation of appropriate prevention and control measures on properties in these areas. The data reported here should be useful in assisting future studies aiming to describe transmission dynamics and to identify risk factors associated with the incidence of the disease. Although this study concerns leptospirosis, the approach and tools applied can be used for any infectious agent.

\section{Conclusion}

Spatial epidemiology and presentation are useful for the visualization of areas at risk for infection and serves to rapidly alert decision makers of impending problems that need immediate action. The vast spread of infectious agents constitutes a constant challenge for those involved with human and animal health, particularly in relation to epidemiological control. In seeking greater control of communicable diseases, it is essential to develop new tools for epidemiological surveillance that are capable of incorporating environmental aspects and risk factors, as well as rapid and automated methods that assist the detection and monitoring of outbreaks in space and time, both for animals and for humans (Bier, 2012).

\section{Acknowledgements}

The present study was approved by the Ethics Committee for Animal Use in the Federal Rural University of Pernambuco under protocol number 036/2012.

\section{References}

AESA, 2011. Executive Agency for Water Management in the State of Paraiba. Accumulated rainfall in 2011. Available at: http://www.aesa.pb.gov.br (accessed on September 2012).

Bailey TC, Gatrell AC, 1995. Interactive spatial data analysis. Harlow: Longman.

Barcellos C, Bastos FI, 1996. Geoprocessamento, ambiente e saúde: uma união possível? Cad Saude Publica 12, 389-397.

Baverud V, Gunnarsson A, Engvall EO, Franzén P, Egenvall A, 2009. Leptospira seroprevalence and associations between seropositivity, clinical disease and host factors in horses. Acta Vet Scand 51, 15.

Belchior NK, Azevedo TS, 2012. Distribuição da leptospirose nos municípios do estado de São Paulo no período de 2008 a 2010. Hygeia, Rev Bras Geogr Med Saude 8, 39-52.

Bier D, 2012. Distribuição espacial e fatores de risco para leptospirose canina na vila pantanal, Curitiba, Paraná, Brasil. MSc thesis - Universidade Federal do Paraná, 141 pp.

Brasil, 1995. Ministry of Health. National Health Foundation. National Epidemiology Center. Coordination of control of zoonoses and poisonous animals. Manual of Leptospirosis. National Health Foundation, 98 pp.

Brasil, 2006. Ministry of Science and Technology. National Institute for Space Research. TerraView ver. 3.1.3. Available at: http://www.dpi.inpe.br/terraview/index.php (accessed on June 2012).

Chiareli D, 2007. Freqüência de aglutininas anti-Leptospira interrogans em equídeos em Minas Gerais, 2003/04. MSc thesis - Universidade Federal de Minas Gerais, Veterinary School, $40 \mathrm{pp}$.

Coiro CJ, Langoni H, Silva RC, 2012. Epidemiological aspects in the Leptospira spp. and Toxoplasma gondii Infection in horses from Botucatu, São Paulo, Brazil. J Equine Vet Sci 32, 620-623.

Finger MAP, 2012. Estudo sorológico e molecular de Leptospira spp. em cavalos carroceiros de Curitiba e Pinhais. PR. Dissertation. Universidade Federal do Paraná.

Ghneim GS, Viers JH, Chomel BB, Kass PH, Descollonges DA, Johnson ML, 2007. Use of a case-control study and geographic information systems to determine environmental and demographic risk factors for canine leptospirosis. Vet Res 38, 37-50.

Gomes AHB, Oliveira FCS, Cavalcanti LA, Conceição IR, Santos GR, Ramalho EJ, Viegas SARA, 2007. Ocorrência de aglutininas anti-leptospira em soro de eqüinos no estado da 
Bahia. Rev Bras Saude Prod An 8, 144-151.

Hashimoto VY, Gonçalves DD, Silva FG, Oliveira RC, Alves LA, Reichmann P, Muller EE, Freitas JC, 2007. Occurrence of antibodies against Leptospira spp. in horses of the urban area of Londrina, Paraná, Brazil. Rev Inst Med Trop São Paulo 49, 327-330.

IBGE, 2012. Brazilian Institute of Geography and Statistics. Rio de Janeiro. Available at: http://www.ibge.gov.br (accessed on May 2012).

Jardim EC, Silva RL, Almeida MMR, Fichtner SS, Cândida MF, 1978. Aglutininas antileptospira em equinos no estado de Goiás. Anais da E. A. V. - UFGO 8, 142-149.

Jones TC, Hunt RD, King NW, 2000. Patologia veterinária. São Paulo: Editora Manole.

Jorge RSP, Ferreira F, Ferreira Neto JS, Vasconcellos SA, Lima ES, Morais ZM, Souza GO, 2011. Exposure of free-ranging wild carnivores, horses and domestic dogs to Leptospira spp. in the northern Pantanal, Brazil. Mem Inst Oswaldo Cruz 106, 441-444.

Jung BY, Lee KW, Ha TY, 2010. Seroprevalence of Leptospira spp. in clinically healthy racing horses in Korea. J Vet Med Sci 72, 197-201.

Langoni H, Silva AV, Pezerico SB, Lima VY, 2004. Anti-leptospire agglutinins in equine sera, from São Paulo, Goiás, and Mato Grosso do Sul, Brazil, 1996-2001. J Venom Anim Toxins 10, 207-218.
Lees VW, Gale SP, 1994. Titers to Leptospira species in horses in Alberta. Can Vet J 35, 636-640.

Linhares GFC, Girio RJS, Linhares DCL, Mondeiro LC, Oliveira APA, 2005. Sorovares de Leptospira interrogans e respectivas prevalências em cavalos da Microrregião de Goiânia, GO. Cienc Anim Bras 6, 255-259.

Magalhães GB, Zanella ME, Sales MCL, 2009. A ocorrência de chuvas e a incidência de leptospirose em Fortaleza-CE. Hygeia, Rev Bras Geogr Med Saude 5, 77-87.

Melo CB, Reis RB, Ko AI, Barreto CMN, Lima AP, Silva AM, 2011. Espacialização da leptospirose em Aracaju, Estado de Sergipe, no período de 2001 a 2007. Rev Soc Bras Med Trop 44, 475-480.

Moraes CCG, Kuroda RBS, Pinho APVB, Ywasaki F, Meneses AMC, Martins AV, Amaral Júnior JM, Dias HLT, Vasconcellos SA, 2010. Pesquisa de anticorpos para sorovares de Leptospira interrogans patogênicas em equídeos criados na ilha de Algodoal, Estado do Pará. Rev Ci Agra 53, 188-194. Odontsetseg N, Boldbaatar D, Mweene AS, Kida H, 2005. Serological prevalence of Leptospira interrogans serovar Bratislava in horses in Mongolia. Vet Rec 157, 518-519.

Oliveira SJ, Pires Neto JAS, 2004. Aspectos etiológicos e de diagnóstico nas leptospiroses. Rev CFMV 10, 36-46.

Soares TSM, Latorre MRDO, Laporta GZ, Buzzar MR, 2010. Análise espacial e sazonal da leptospirose no município de São Paulo, SP, 1998 a 2006. Rev Saude Publica 44, 283-291. 